\title{
Primary hemangioblastoma of the kidney with molecular analyses by next generation sequencing: a case report and review of the literature
}

Xintong Wang, George K. Haines III, Meenakshi Mehrotra, Jane Houldsworth and Qiusheng Si*

\begin{abstract}
Background: Hemangioblastoma is an indolent mesenchymal tumor most frequently occurring in the central nervous system (CNS), but can also arise extraneuraxially, as part of Von Hippel-Lindau (VHL) disease or in sporadic tumors. Extraneuraxial hemangioblastomas occur outside the central nervous system. It includes tumors arising from the nervous paraneuraxial structures and visceral organs. Sporadic hemangioblastoma of the kidney, a rare subset of extraneuraxial hemangioblastomas, is an under-recognized renal neoplasm. There have been only 25 cases described to date in the English language literature. We report herein one additional sporadic tumor in a patient without VHL disease.
\end{abstract}

Case presentation: A 61 year old male presenting with gross hematuria was found to have a $3.5 \mathrm{~cm}$ renal mass at the lateral mid to lower pole of the left kidney on computed tomography urogram. The patient underwent a partial nephrectomy for the mass. Pathological examination showed a well-circumscribed non-encapsulated tumor composed of sheets of large polygonal cells traversed by a rich vascular network. The tumor cells showed clear to eosinophilic cytoplasm and overall bland nuclei. The diagnosis of hemangioblastoma was confirmed by positive immunostaining for alpha-inhibin, S100, neuron-specific enolase, and PAX8. No significant gene mutations, including VHL gene and copy number changes were detected in the tumor using next generation sequencing supporting the diagnosis of sporadic renal hemangioblastoma.

Conclusion: Sporadic renal hemangioblastoma is a rare subset of extraneuraxial hemangioblastomas. We report one such tumor in a patient without clinical or molecular evidence of $\mathrm{VHL}$ disease. The literature was reviewed to better understand the clinical, radiological, pathological, and molecular features of this neoplasm. The majority of renal hemangioblastomas showed positive immunostaining for PAX8, which supports the idea that the immunoprofiles of extraneuraxial hemangioblastomas can vary depending on sites of origin. Diagnosis of renal hemangioblastoma is challenging because of its rarity and overlapping microscopic and immunophenotypic features with other renal tumors, including clear cell renal cell carcinoma. In some cases, molecular or genetic studies may be necessary to obtain an accurate diagnosis. Since renal hemangioblastoma is clinically benign, recognition of this pathological entity is important to avoid unnecessary over-treatment.

Keywords: Renal hemangioblastoma, Von Hippel-Lindau disease, Next generation sequencing

\footnotetext{
* Correspondence: qiusheng.si@mountsinai.org

Department of Pathology, Molecular and Cell-Based Medicine, Icahn School of Medicine at Mount Sinai, New York, NY, USA
}

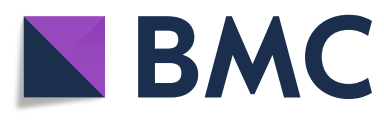

(c) The Author(s). 2022 Open Access This article is licensed under a Creative Commons Attribution 4.0 International License, which permits use, sharing, adaptation, distribution and reproduction in any medium or format, as long as you give appropriate credit to the original author(s) and the source, provide a link to the Creative Commons licence, and indicate if changes were made. The images or other third party material in this article are included in the article's Creative Commons licence, unless indicated otherwise in a credit line to the material. If material is not included in the article's Creative Commons licence and your intended use is not permitted by statutory regulation or exceeds the permitted use, you will need to obtain permission directly from the copyright holder. To view a copy of this licence, visit http://creativecommons.org/licenses/by/4.0/ The Creative Commons Public Domain Dedication waiver (http://creativecommons.org/publicdomain/zero/1.0/) applies to the data made available in this article, unless otherwise stated in a credit line to the data. 


\section{Background}

Hemangioblastoma is an indolent tumor of mesenchymal cells that most frequently occurs in the central nervous system (CNS), mainly in the cerebellum. Most tumors are sporadic, while 20-30\% occur in patients with Von-Hippel-Lindau (VHL) disease [1]. Extraneuraxial hemangioblastomas, (hemangioblastomas occurring outside the central nervous system), including tumors arising from the paraneuraxial structures, soft tissue, bone and visceral organs. Extraneural hemangioblastomas seem to be identical to the CNS hemangioblastomas morphologically and immunophenotypically, but there are certain differences. Renal hemangioblastoma is a rare subset of extraneuraxial hemangioblastomas, which usually occurs in the setting of known VHL disease. But, can also occur sporadically. To date, only 25 cases of sporadic renal hemangioblastomas have been described in the English language literature [2-16]. We report herein one such tumor in a patient without clinical or molecular evidence of VHL disease, and review the literature to better understand its clinical, radiological, pathological and molecular features. Since renal hemangioblastoma is clinically benign, a correct recognition of this pathological entity is important to avoid unnecessary clinical treatment.

\section{Case presentation}

A 61 year-old man presented with one episode of gross hematuria without fever, flank pain, pain with urination, weight loss, or neurological symptoms. The patient had a past medical history of coronary artery disease and well-controlled hypertension. A computed tomography (CT) urogram showed a $3.5 \times 2.1 \times 1.3 \mathrm{~cm}$, arterially enhancing mass, at the lateral mid to lower pole of the left kidney, along with a branching calculus in left lower pole renal calyces. These findings were suspicious for a renal cell carcinoma. The laboratory examination revealed a normal creatinine. There was no family history of VHL disease or neoplastic diseases. A cystoscopy was performed and revealed no tumor in the urethra, bladder or ureter. One month later, the patient underwent a laparoscopic left partial nephrectomy. Gross examination of the specimen revealed a well-circumscribed but nonencapsulated round mass, measuring $3.0 \times 2.1 \times 1.3 \mathrm{~cm}$. Cut surfaces revealed the tumor was tan-white in color, with partial fibrosis, and mild hemorrhage. Histologically, under low power, the tumor was slightly lobulated, traversed by a prominent vascular network with thinwalled blood vessels (Fig. 1B), in a background of hyalinized and sclerotic stroma (Fig. 1A). On high power, the tumor cells were slightly variable in size, oval to polygonal in shape, and with abundant clear to eosinophilic cytoplasm (Fig. 2A and B) with occasional fine vacuoles (Fig. 2C) and eosinophilic hyaline globules (Fig. 2D). Most tumor cell nuclei were bland with inconspicuous nucleoli, although focal mild pleomorphism was present. There was no tumor necrosis or mitotic figures. Immunohistochemically, the tumor cells diffusely expressed S100 (Fig. 3A), alpha-inhibin (Fig. 3B), neuron-specific enolase (NSE), vimentin and PAX8 (Fig. 3C). AE1/AE3 showed only weak, focal cytoplasmic staining. The tumor cells were negative for epithelial membrane

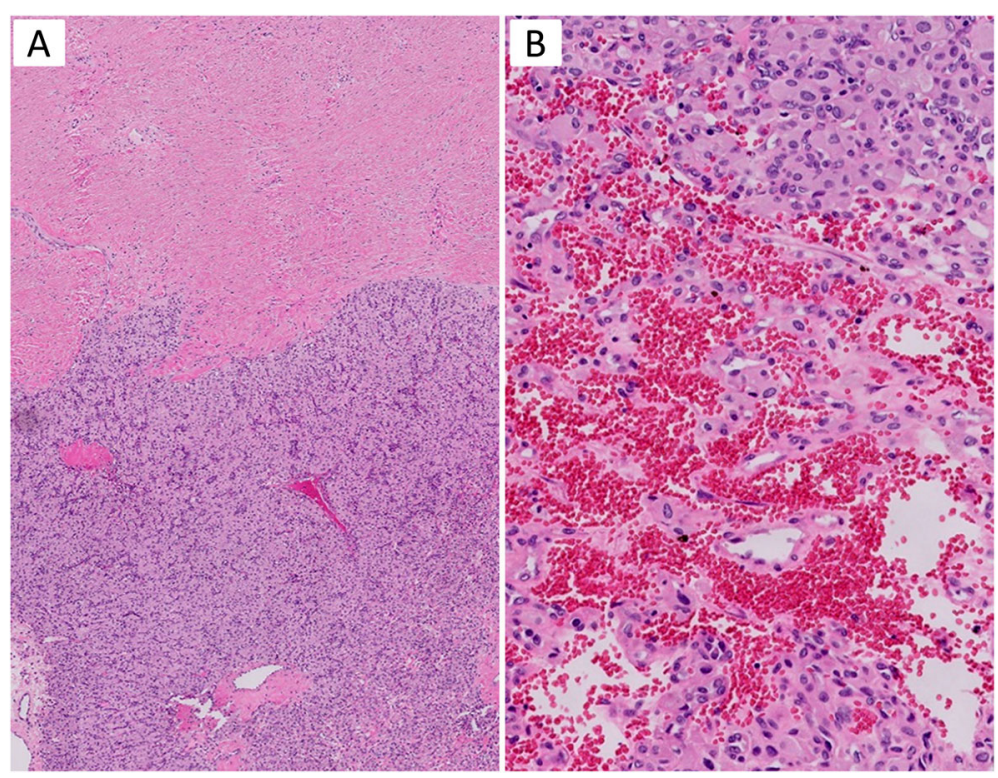

Fig. 1 Microscopic architectural features of renal hemangioblastoma. A Low magnification demonstrates a solid mass divided into lobulated nodules by thick collagenous septa $(H \& E, \times 50)$. B The tumor is traversed by arborizing thin-walled vessels (H\&E. $\times$ 200) 


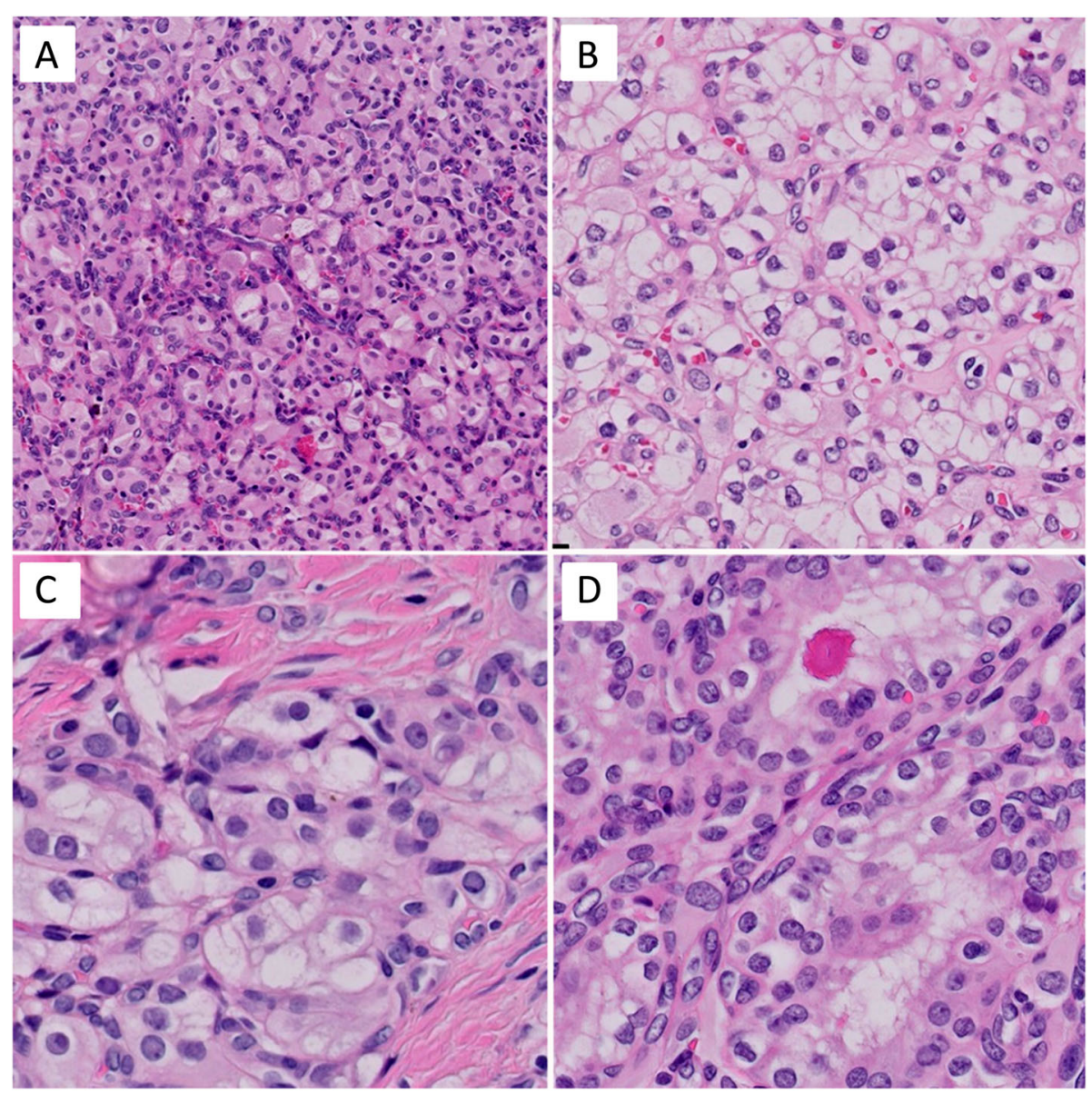

Fig. 2 Microscopic cytologic features of renal hemangioblastoma. A Epithelioid tumor cells showed eosinophilic cytoplasm (H\&E, x 200). B Few tumor cells showed clear cytoplasm (H\&E, x 400). C Some tumor cells contain numerous well-delineated vacuoles (H\&E, x 400). D Eosinophilic hyaline globules were found in some tumor cells $(H \& E, x 400)$
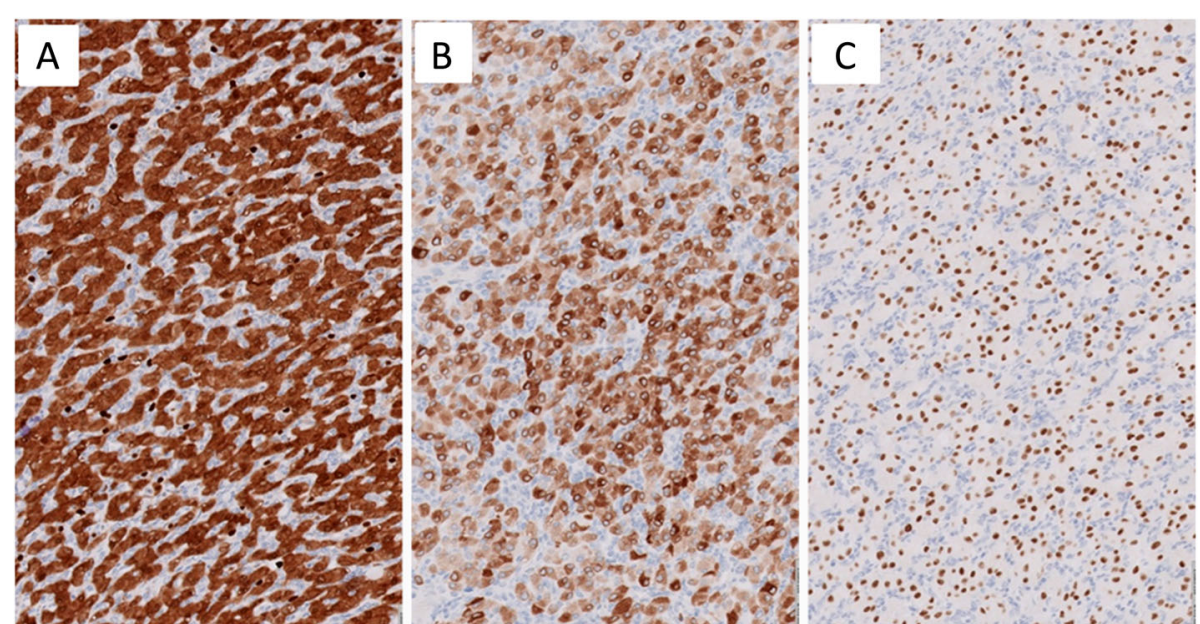

Fig. 3 Immunohistochemical findings of renal hemangioblastoma. Tumor cells demonstrate diffuse immunoreactivity for (A) S100, (B) alphainhibin, and (C) PAX8 
antigen (EMA), carbonic anhydrase 9 (CA9), CD10, KRT7, CD117, p504s, synaptophysin, chromogranin, melanin A, HMB45 and steroidogenic factor 1 (SF-1). Ki-67 stain showed very low proliferative index $(<1 \%)$. Extracted genomic DNA from formalin fixed paraffinembedded material (50\% tumor cellularity) was submitted for next generation sequencing (NGS) using the Oncomine Comprehensive Plus panel (ThermoFisher) enabling the detection of variants in the full coding sequence of 227 genes and hot spots of 165 genes, and the detection of copy number variants of 333 genes, including the entire coding sequence of $V H L$. Two variants of uncertain significance were detected in NOTCH1 (c.6061G $>$ T, p.V2021F, variant allele frequency $=52 \%$ ) and $A P C$ (c.7459T>C, p.S2487P, variant allele frequency $=52 \%$ ), but no copy number changes were detected. Overall, the histological, immunohistochemical, and molecular findings supported the diagnosis of sporadic hemangioblastoma of the kidney. The postoperative course of the patient was uncomplicated, and there was no evidence of tumor recurrence or metastasis on follow-up 10 months after the surgery.

\section{Discussion}

Hemangioblastoma is an uncommon, benign neoplasm that mainly occurs in the CNS, especially in the cerebellum. Extraneuraxial hemangioblastomas are rare subsets of hemangioblastomas arising outside of the CNS. There have been about 200 cases of extraneuraxial hemangioblastomas reported to date in the literature, as part of VHL disease or as sporadic tumors, and up to 140 cases were from nervous paraneuraxial structures [14]. Sporadic primary hemangioblastoma of the kidney is an even rarer neoplasm, with only 25 cases found in the English language literature (Table 1) [2-17]. Clinically, sporadic renal hemangioblastoma is a benign neoplasm, similar to other subtypes of extraneuraxial hemangioblastomas and the sporadic CNS hemangioblastoma.

As detailed in Table 1, 25 patients with sporadic renal hemangioblastomas were adults and only one was child (diagnosed at age of 16 years) [5], with the median age at diagnosis of 48 years, ranging from 16 to 71 years. Fourteen patients were male and 12 patients were female $(\mathrm{M}: \mathrm{F}=1.17)$. In 15 of 26 patients, tumors were located in the right kidney, and the upper pole was the most common site. The average tumor size was $4.2 \mathrm{~cm}$ (range $1.2-15 \mathrm{~cm})[5,11]$. Overall, $60 \%$ of patients were asymptomatic, $24 \%$ had hematuria, $12 \%$ experienced lower back or abdominal pain, while only one patient presented with systemic symptoms, such as fever and weight loss [11]. None of the patients included in this study had VHL disease. One patient with possible VHL disease [13] was excluded from review.
Since this tumor is so rare, there are minimal descriptions of its characteristic radiological features. He et al. described peripheral nodular enhancement in the corticomedullary phase, progressive centripetal enhancement in the nephrographic and delayed phases, and sometimes complete "filling in" in the delayed phase in 2 patients with renal hemangioblastomas [16].

All reported tumors were removed surgically, with almost all (25/26) showing unilateral, unifocal distributions, with one exception [11] being a patient with 3 lesions in the left kidney (right kidney uninvolved). All lesions were confirmed as renal hemangioblastoma histologically. Macroscopically, renal hemangioblastoma displays a solid, occasionally cystic cut surface [7]. Microscopically, similarly to CNS hemangioblastoma, renal hemangioblastoma is composed of welldemarcated, large sheets of polygonal cells, with a prominent, arborizing vascular network. The tumor cells are variable in size with clear to eosinophilic cytoplasm, which commonly contains sharply delineated fine lipid vacuoles. Rhabdoid features were reported in one tumor [7]. Most of the tumors appear bland [2], but some tumors showed mild to moderate nuclear pleomorphism [3]. Mitotic figures were rare in the reported tumors.

Immunohistochemically, as detailed in Table 2, almost all of the renal hemangioblastomas demonstrated diffuse positivity for alpha-inhibin (24/26), NSE (23/23), S100 protein (25/25), and vimentin $(19 / 21)$, and negativity for neuroendocrine markers (synaptophysin, chromogranin A), melanocytic markers (HMB45, melan-A), endothelial markers (CD31, CD34), and mesothelial markers (calretinin, WT-1). In 3 of 21 reported cases, tumor cells expressed focal, patchy positivity for AE1/AE3 [10, 16], including the present tumor. The majority of renal hemangioblastomas exhibited no immunoreaction for muscle, such as desmin [2-4], but two tumors were noted to have focal expression of smooth muscle actin [2, 15]. CD10 was reported to be positive in $7 / 16$ tumors $[7,8,10,14,15]$. EMA was positive in $5 / 15$ tumors $[4,7,8,14,15]$ and CA9 was positive in $3 / 4$ tumors $[4,8,12]$.

Including the present case, the diffuse and strong nuclear positivity for PAX8 was observed in 8/14 tumors [10-12, 14-16], and PAX2 was positive in 2 reported tumors $[8,12]$. PAX8 and PAX2 are cell lineage specific transcription factors that play a crucial role in the organogenesis of the kidney [17]. Both factors are expressed in normal kidneys as well as in many renal epithelial neoplasms such as renal cell carcinoma (RCC). Zhao et al, has put forward a hypothesis suggesting that the immunoprofile of extraneuraxial hemangioblastomas can vary with different sites of origin [10]. With the findings of positivity for PAX8 and/or PAX2 in the above- 
Table 1 Reported cases of sporadic renal hemangioblastoma

\begin{tabular}{|c|c|c|c|c|c|c|c|c|c|}
\hline Case\# & Reference & Age & Gender & $\begin{array}{l}\text { Tumor } \\
\text { laterality }\end{array}$ & $\begin{array}{l}\text { Site of } \\
\text { kidney }\end{array}$ & $\begin{array}{l}\text { Size of } \\
\text { tumor }(\mathrm{cm})\end{array}$ & $\begin{array}{l}\text { Clinical } \\
\text { presentation }\end{array}$ & $\begin{array}{l}\text { Presence of VHL disease (VHL } \\
\text { genetic test perfromed) }\end{array}$ & Outcome \\
\hline 1 & Nonaka et al 2007 & 71 & $\mathrm{~F}$ & Right & $\begin{array}{l}\text { Upper } \\
\text { pole }\end{array}$ & 6.8 & Asymptomatic & Not stated & $\begin{array}{l}\text { ANED, } 9 \\
\text { years }\end{array}$ \\
\hline 2 & $\begin{array}{l}\text { Ip et al 2010, case } \\
1\end{array}$ & 58 & M & Right & Mid pole & 5.5 & Hematuria & No & $\begin{array}{l}\text { ANED, } 2 \\
\text { years }\end{array}$ \\
\hline 3 & $\begin{array}{l}\text { Ip et al 2010, case } \\
2\end{array}$ & 55 & $\mathrm{~F}$ & Right & $\begin{array}{l}\text { Lower } \\
\text { pole }\end{array}$ & 3.5 & $\begin{array}{l}\text { Low back } \\
\text { pain }\end{array}$ & No & $\begin{array}{l}\text { ANED, } 4 \\
\text { years }\end{array}$ \\
\hline 4 & Verine et al 2011 & 64 & M & Left & $\begin{array}{l}\text { Upper } \\
\text { pole }\end{array}$ & 3.2 & Asymptomatic & No & $\begin{array}{l}\text { ANED, } 1 \\
\text { year }\end{array}$ \\
\hline 5 & Liu et al 2012 & 16 & $\mathrm{~F}$ & Left & $\begin{array}{l}\text { Upper } \\
\text { pole }\end{array}$ & 1.2 & Hematuria & No & $\begin{array}{l}\text { ANED, } 5 \\
\text { months }\end{array}$ \\
\hline 6 & Wang et al 2012 & 29 & M & Right & $\begin{array}{l}\text { Lower } \\
\text { pole }\end{array}$ & 3.1 & Asymptomatic & No & $\begin{array}{l}\text { ANED, } 20 \\
\text { months }\end{array}$ \\
\hline 7 & Yin et al 2012 & 61 & M & Right & $\begin{array}{l}\text { Upper } \\
\text { pole }\end{array}$ & 5.3 & Asymptomatic & No & $\begin{array}{l}\text { ANED, } 1 \\
\text { year }\end{array}$ \\
\hline 8 & Jiang et al 2013 & 57 & $\mathrm{~F}$ & Right & $\begin{array}{l}\text { Upper } \\
\text { pole }\end{array}$ & 3 & Asymptomatic & No & $\begin{array}{l}\text { ANED, } 6 \\
\text { months }\end{array}$ \\
\hline 9 & Wang et al 2013 & 61 & M & Right & $\begin{array}{l}\text { Upper } \\
\text { pole }\end{array}$ & 6.5 & Asymptomatic & No & $\begin{array}{l}\text { ANED, } 1 \\
\text { year }\end{array}$ \\
\hline 10 & Zhao et al 2013 & 51 & $\mathrm{~F}$ & Right & $\begin{array}{l}\text { Lower } \\
\text { pole }\end{array}$ & 5.5 & $\begin{array}{l}\text { Abdominal } \\
\text { pain }\end{array}$ & No & $\begin{array}{l}\text { ANED, } 1 \\
\text { year }\end{array}$ \\
\hline 11 & $\begin{array}{l}\text { Doyle et al 2014, } \\
\text { case } 1\end{array}$ & 58 & M & Right & n.i. & 4.5 & $\begin{array}{l}\text { Fevers and } \\
\text { weight loss }\end{array}$ & No & $\begin{array}{l}\text { ANED, } 19 \\
\text { months }\end{array}$ \\
\hline 12 & $\begin{array}{l}\text { Doyle et al 2014, } \\
\text { case } 2\end{array}$ & 42 & $\mathrm{~F}$ & Left & n.i. & $\begin{array}{l}15.0,4.0,2.0 \\
(3 \text { tumors) }\end{array}$ & Hematuria & No & $\begin{array}{l}\text { ANED, } 5 \\
\text { months }\end{array}$ \\
\hline 13 & $\begin{array}{l}\text { Doyle et al 2014, } \\
\text { case } 3\end{array}$ & 29 & M & Right & n.i. & 2.7 & Asymptomatic & No & $\begin{array}{l}\text { ANED, } 32 \\
\text { months }\end{array}$ \\
\hline 14 & Kurado et al 2015 & 37 & M & Left & $\begin{array}{l}\text { Upper } \\
\text { pole }\end{array}$ & 3.6 & Asymptomatic & No & n.i. \\
\hline 15 & $\begin{array}{l}\text { Wu et al 2015, } \\
\text { case } 2\end{array}$ & 48 & M & Right & $\begin{array}{l}\text { Lower } \\
\text { pole }\end{array}$ & 2.3 & Asymptomatic & No & $\begin{array}{l}\text { ANED, } 42 \\
\text { months }\end{array}$ \\
\hline 16 & $\begin{array}{l}\text { Wu et al 2015, } \\
\text { case } 3\end{array}$ & 25 & M & Left & n.i. & 4.1 & Asymptomatic & No & $\begin{array}{l}\text { ANED, } 27 \\
\text { months }\end{array}$ \\
\hline 17 & $\begin{array}{l}\text { Wu et al 2015, } \\
\text { case } 4\end{array}$ & 36 & $\mathrm{~F}$ & Left & n.i. & n.i. & Asymptomatic & No & $\begin{array}{l}\text { ANED, } 3 \\
\text { months }\end{array}$ \\
\hline 18 & $\begin{array}{l}\text { Wu et al 2015, } \\
\text { case } 5\end{array}$ & 57 & $\mathrm{~F}$ & Right & n.i. & n.i. & Asymptomatic & No & $\begin{array}{l}\text { ANED, } 5 \\
\text { months }\end{array}$ \\
\hline 19 & $\begin{array}{l}\text { Muscarella et al } \\
2018 \text {, case } 7\end{array}$ & 21 & M & Left & n.i. & 3.5 & Hematuria & No & $\begin{array}{l}\text { ANED, } 8 \\
\text { years }\end{array}$ \\
\hline 20 & $\begin{array}{l}\text { Muscarella et al } \\
2018 \text {, case } 8\end{array}$ & 19 & $\mathrm{~F}$ & Right & n.i. & 3 & Hematuria & No & $\begin{array}{l}\text { ANED, } 9 \\
\text { years }\end{array}$ \\
\hline 21 & $\begin{array}{l}\text { Muscarella et al } \\
2018 \text {, case } 9\end{array}$ & 28 & $\mathrm{~F}$ & Right & n.i. & 3.5 & Asymptomatic & No & $\begin{array}{l}\text { ANED, } 7 \\
\text { years }\end{array}$ \\
\hline 22 & $\begin{array}{l}\text { Muscarella et al } \\
2018 \text {, case } 10\end{array}$ & 47 & M & Right & n.i. & n.i. & n.i. & No & n.i. \\
\hline 23 & $\begin{array}{l}\text { Oberhammer et al } \\
2019\end{array}$ & 72 & $\mathrm{~F}$ & Left & $\begin{array}{l}\text { Lower } \\
\text { pole }\end{array}$ & 4.2 & Asymptomatic & No & $\begin{array}{l}\text { ANED, } 6 \\
\text { months }\end{array}$ \\
\hline 24 & $\begin{array}{l}\text { He et al 2021, } \\
\text { case } 1\end{array}$ & 45 & M & Left & $\begin{array}{l}\text { Lower } \\
\text { pole }\end{array}$ & 3.7 & $\begin{array}{l}\text { Abdomenal } \\
\text { pain }\end{array}$ & No & $\begin{array}{l}\text { ANED, } 5 \\
\text { years }\end{array}$ \\
\hline 25 & $\begin{array}{l}\text { He et al 2021, } \\
\text { case } 2\end{array}$ & 42 & $\mathrm{~F}$ & Left & n.i. & 2.9 & Asymptomatic & No & $\begin{array}{l}\text { ANED, } 3 \\
\text { years }\end{array}$ \\
\hline 26 & Current case & 61 & M & Left & $\begin{array}{l}\text { Lower } \\
\text { pole }\end{array}$ & 3 & Hematuria & No & $\begin{array}{l}\text { ANED, } 10 \\
\text { months }\end{array}$ \\
\hline
\end{tabular}




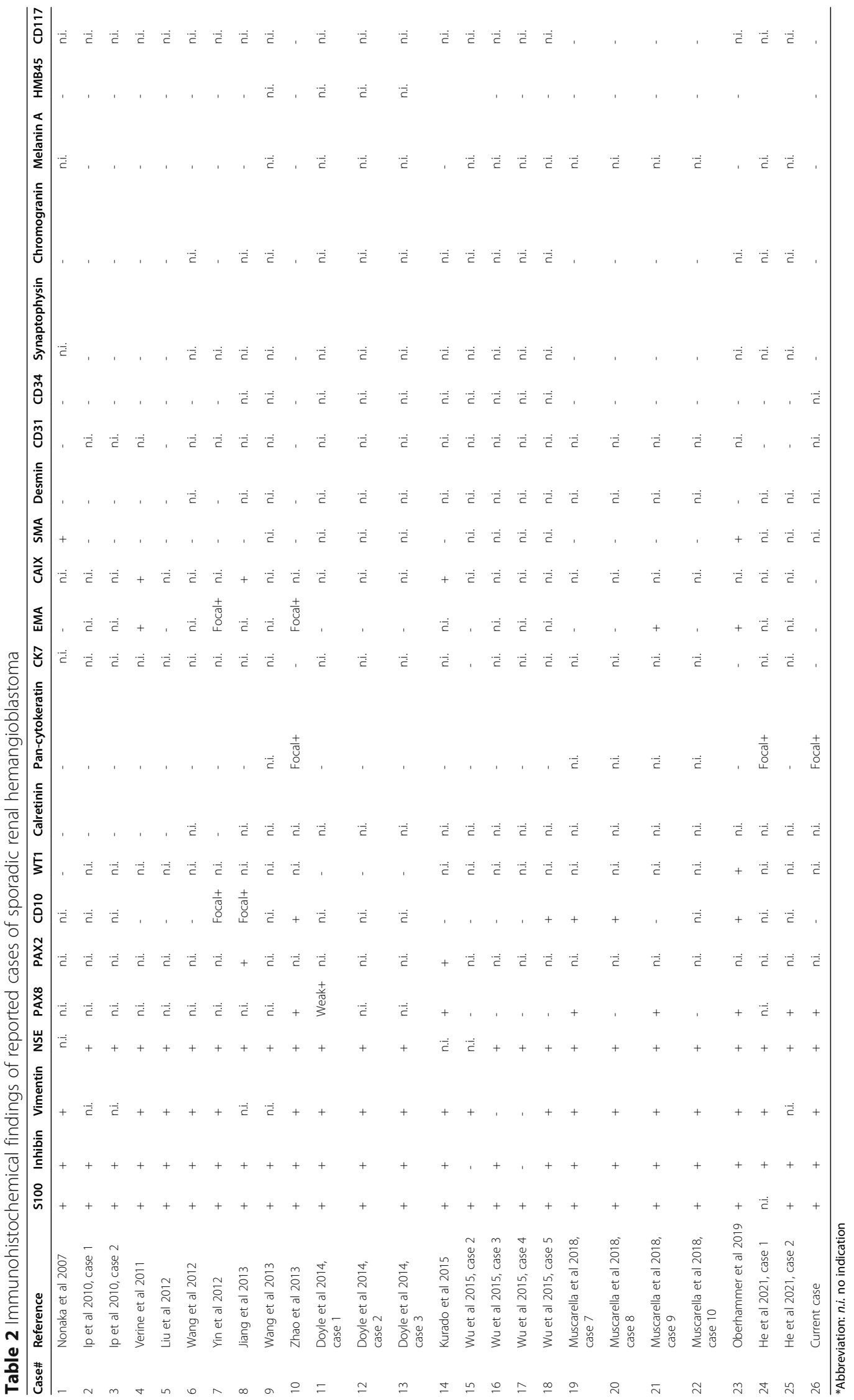


mentioned 9 tumors, we agree with the hypothesis that renal hemangioblastomas are capable of expressing kidney-specific antigens.

Renal hemangioblastoma is likely to be an underrecognized tumor of kidney due to its rarity. This indolent neoplasm can be mistaken for various malignancies, including clear cell RCC or epithelioid angiomyolipoma. Clear cell RCC share similar morphological characteristics with renal hemangioblastomas, such as a clear cytoplasm and a prominent vascular network. The most useful feature to differentiate clear cell RCC from renal hemangioblastoma is the absence of fine cytoplasmic lipid vacuoles, which is predominantly present in renal hemangioblastoma. Immunohistochemically, clear cell RCC is usually positive for AE1/AE3, EMA, CA9, CD10 and PAX8, but negative for alpha-inhibin, S100, and NSE. However, to add to the confusion, Montironi et al [18] reported clear cell RCCs in 2 patients with $60-70 \%$ of tumor cells showing hemangioblastoma-like features. In those reported cases, the tumor cells expressed alphainhibin and S100 in the hemangioblastoma-like part only (not in the clear cell RCC part), but PAX8, CD10, and RCC were positive in both components of the tumor. After carefully reviewing the histologic morphology in our present case, we have found $\sim 10 \%$ of tumor cells showing clear cytoplasm, but all tumor cells stained consistently for S100, alpha-inhibin, NSE, Vimentin, and negative for CD10 and CA9. These findings supported a diagnosis of renal hemangioblastoma. Another major mimicker of renal hemangioblastoma is epithelioid angiomyolipoma, which also possesses sheets of polygonal cells with an abundant cytoplasm and a rich vascular network. The key feature to differentiate renal hemangioblastoma from epithelioid angiomyolipomas is that epithelioid angiomyolipomas usually show reticulated cytoplasm instead of a lipid containing vacuolated cytoplasm. Immunohistochemically, epithelioid angiomyolipomas are usually HMB45 positive, melan-A positive, but alpha-inhibin negative. Other differential diagnoses include renal oncocytoma and intrarenal ectopic adrenal tissue. Oncocytoma shares similar morphological characteristics with hemangioblastomas, such as eosinophilic cytoplasm and eosinophilic hyaline globules, but fine cytoplasmic lipid vacuoles are absent in oncocytoma. Immunohistochemically, oncocytoma is usually positive for EMA, CD117, and PAX8, but negative for CD10, alpha-inhibin and vimentin. Intrarenal ectopic adrenal tissue can be found in $6 \%$ of the general population. It commonly composed of sheets or glands of cells with distinct cell borders and abundant foamy cytoplasm, traversed by interspersed blood vessels in a sinusoidal pattern, which features are similar to the hemangioblastoma. Although adrenal cortical cells are positive for a-inhibin, they also show immunoreactivity for other adrenocortical markers like melan-A and SF-1, but are negative for PAX8, S100 and vimentin.

In some reported cases, molecular genetic studies were performed, including polymerase chain reaction (PCR) analysis for exons of $V H L$ gene (tested in 6 studies, 9 patients) $[3,6,8,12,14,15]$, loss of heterozygosity (LOH) analysis for chromosome $3 p$ genes (tested in 2 studies, 5 patients) $[12,14]$, and fluorescence in situ hybridization (FISH) for chromosome 3p deletion (tested in 1 study, 1 patient) [8]. Overall, no $V H L$ gene mutation, loss of heterozygosity (LOH) of chromosome $3 p$ or chromosome $3 p$ deletion were detected in the reported 9 tumors. We agree with the hypothesis put forward by Muscarella et al. that 1) the genetic changes may be localized to the intronic or regulatory regions of $V H L$ gene; 2) the genetic anomaly may involve other genes, which interplay with $V H L$ gene expression; 3) alternative tumor genetic mechanisms [14]. Since NGS can afford a comprehensive molecular profiling approach, we submitted the tumor for NGS that interrogated DNA alterations in over 400 genes, with no significant alterations detected. At the time of our study, this is the first time that NGS analysis has been described in sporadic renal hemangioblastoma. However, no significant gene mutations, including VHL gene were detected in our tumor. Two variants of uncertain significance were detected in NOTCH1 and APC, but no copy number changes were detected. It may require a large cohort study to address the significance of these two variants in renal hemangioblastoma. Therefore, the tumor genetic mechanism of renal hemangioblastoma, at least in our tumor, remained unclear.

\section{Conclusion}

Sporadic renal hemangioblastoma is a rare subset of extraneuraxial hemangioblastomas. We report herein one such tumor in a patient without clinical or molecular evidence of VHL disease, and reviewed the literature to better understand the clinical, radiological, pathologic and molecular features of this neoplasm. From our review cases and the present case, we have found that the majority of renal hemangioblastomas showed positive immunostaining for PAX8, which supports the idea that the immunoprofile of extraneuraxial hemangioblastomas can vary depending on sites of origin. Diagnosis of renal hemangioblastoma is challenging because of its rarity and overlapping microscopic and immunophenotypical features with renal cell tumors (PAX8+ and CD10+), especially clear cell renal cell carcinoma. However, accurate diagnosis is necessary, since renal hemangioblastoma is clinically benign diagnosis, and a correct recognition of this pathological entity is important to avoid unnecessary treatment. 


\section{Abbreviations}

CA9: carbonic anhydrase 9; CNS: central nervous system; CT: computed tomography; EMA: epithelial membrane antigen; NGS: next generation sequencing; NSE: neuron-specific enolase; RCC: renal cell carcinoma; VHL: Von Hippel-Lindau

\section{Acknowledgements}

Not applicable.

\section{Authors' contributions}

Xintong Wang; Data Collection, Manuscript writing. George K. Haines III; Meenakshi Mehrotra; Jane Houldsworth; Qiusheng Si: Manuscript editing. The author(s) read and approved the final manuscript.

\section{Funding}

No funding.

\section{Availability of data and materials}

The dataset supporting the conclusions of this article is included within the article.

\section{Declarations}

\section{Ethics approval and consent to participate}

All ethical approval and consent procedures were approved by the Medical Ethical Committee of Icahn School of Medicine at Mount Sinai. According to the institutional guidelines, the patient's signed privacy consent is not necessary for a single case report with de-identified patient specific information.

\section{Consent for publication}

Not applicable.

\section{Competing interests}

The authors declare no conflict of interest/competing interests in publishing the present manuscript.

Received: 14 October 2021 Accepted: 9 February 2022

Published online: 27 February 2022

\section{References}

1. Byun J, Yoo HJ, Kim JH, Kim YH, Cho YH, Hong SH, et al. Growth rate and fate of untreated hemangioblastomas: clinical assessment of the experience of a single institution. J Neurooncol. 2019;144(1):147-54.

2. Nonaka D, Rodriguez J, Rosai J. Extraneural hemangioblastoma: a report of 5 cases. Am J Surg Pathol. 2007;31(10):1545-51.

3. Ip YT, Yuan JQ, Cheung H, Chan JK. Sporadic hemangioblastoma of the kidney: an underrecognized pseudomalignant tumor? Am J Surg Pathol. 2010;34(11):1695-700.

4. Verine J, Sandid W, Miquel C, Vignaud JM, Mongiat-Artus P. Sporadic hemangioblastoma of the kidney: an underrecognized pseudomalignant tumor? Am J Surg Pathol. 2011;35(4):623-4.

5. Liu Y, Qiu XS, Wang EH. Sporadic hemangioblastoma of the kidney: a rare renal tumor. Diagn Pathol. 2012;7:49.

6. Wang CC, Wang SM, Liau JY. Sporadic hemangioblastoma of the kidney in a 29-year-old man. Int J Surg Pathol. 2012;20(5):519-22.

7. Yin WH, Li J, Chan JK. Sporadic haemangioblastoma of the kidney with rhabdoid features and focal CD10 expression: report of a case and literature review. Diagn Pathol. 2012;7:39

8. Jiang JG, Rao Q, Xia QY, Tu P, Lu ZF, Shen Q, et al. Sporadic hemangioblastoma of the kidney with PAX2 and focal CD10 expression: report of a case. Int J Clin Exp Pathol. 2013;6(9):1953-6.

9. Wang Y, Wei C, Mou L, Zhang Q, Cui Z, Li X, et al. Sporadic renal haemangioblastoma: Case report and review of the literature. Oncol Lett. 2013:5(1):360-2.

10. Zhao M, Williamson SR, Yu J, Xia W, Li C, Zheng J, et al. PAX8 expression in sporadic hemangioblastoma of the kidney supports a primary renal cell lineage: implications for differential diagnosis. Hum Pathol. 2013;44(10): 2247-55.

11. Doyle $L A$, Fletcher CD. Peripheral hemangioblastoma: clinicopathologic characterization in a series of 22 cases. Am J Surg Pathol. 2014;38(1):119-27.
12. Kuroda N, Agatsuma Y, Tamura M, Martinek P, Hes O, Michal M. Sporadic renal hemangioblastoma with CA9, PAX2 and PAX8 expression: diagnostic pitfall in the differential diagnosis from clear cell renal cell carcinoma. Int J Clin Exp Pathol. 2015:8(2):2131-8.

13. Wu Y, Wang T, Zhang PP, Yang X, Wang J, Wang CF. Extraneural hemangioblastoma of the kidney: the challenge for clinicopathological diagnosis. J Clin Pathol. 2015;68(12):1020-5.

14. Muscarella LA, Bisceglia M, Galliani CA, Zidar N, Ben-Dor DJ, Pasquinelli G, et al. Extraneuraxial hemangioblastoma: A clinicopathologic study of 10 cases with molecular analysis of the VHL gene. Pathol Res Pract. 2018;214(8): $1156-65$.

15. Oberhammer L, Mitterberger MJ, Lusuardi L, Kunit T, Drerup M, Colleselli D, et al. Sporadic renal hemangioblastoma: A case report of a rare benign renal tumor. Clin Case Rep. 2019;7(12):2321-6.

16. He J, Liu N, Liu W, Zhou W, Wang Q, Hu H. CT and MRI characteristic findings of sporadic renal hemangioblastoma: Two case reports. Medicine (Baltimore). 2021;100(6):e24629.

17. Chi N, Epstein JA. Getting your Pax straight: Pax proteins in development and disease. Trends Genet. 2002;18(1):41-7.

18. Montironi R, Lopez-Beltran A, Cheng L, Galosi AB, Montorsi F, Scarpelli M. Clear cell renal cell carcinoma (ccRCC) with hemangioblastoma-like features: a previously unreported pattern of $\mathrm{ccRCC}$ with possible clinical significance. Eur Urol. 2014;66(5):806-10.

\section{Publisher's Note}

Springer Nature remains neutral with regard to jurisdictional claims in published maps and institutional affiliations.
Ready to submit your research? Choose BMC and benefit from:

- fast, convenient online submission

- thorough peer review by experienced researchers in your field

- rapid publication on acceptance

- support for research data, including large and complex data types

- gold Open Access which fosters wider collaboration and increased citations

- maximum visibility for your research: over $100 \mathrm{M}$ website views per year

At BMC, research is always in progress.

Learn more biomedcentral.com/submissions 